\title{
Magnesium Borohydride: From Hydrogen Storage to Magnesium
} Battery**

\author{
Rana Mohtadi,* Masaki Matsui, Timothy S. Arthur, and Son-Jong Hwang
}

Since Bogdanović and Schwickardi illustrated the possibility of reversibly storing hydrogen in sodium alanate ${ }^{[1]}$ extensive research efforts have been dedicated to investigating the hydrogen storage potential of complex metal hydrides. In particular, borohydrides have attracted great interest because of their superior gravimetric hydrogen content. ${ }^{[2]}$ Of these, magnesium borohydride $\mathrm{Mg}\left(\mathrm{BH}_{4}\right)_{2}$, first reported in $1950^{[3]}$ and more recently studied for hydrogen storage, has attracted attention because of its relatively low hydrogen-release temperature and reversibility. ${ }^{[2 a, 4]}$ Furthermore, borohydrides are strong reducing agents that are widely used in organic and inorganic syntheses. This reducing power translates to high stability against electrochemical reduction; this stability could be exploited in highly reductive environments, such as battery anodes. Therefore, for the first time, we have conducted research towards harnessing this property of borohydrides for their use in rechargeable batteries. In particular, we have been focusing on utilizing a $\mathrm{Mg}\left(\mathrm{BH}_{4}\right)_{2}$ based electrolyte in a rechargeable magnesium battery.

Recently, magnesium batteries have received increased attention as alternatives to the lithium-based battery because of the high volumetric capacity $\left(3832 \mathrm{~mA} \mathrm{~h} \mathrm{~cm}^{-3}\right)$, improved safety (nondendritic), and abundance of $\mathrm{Mg}$ metal. ${ }^{[5]}$ Despite the potential of $\mathrm{Mg}$ batteries, several key challenges need to be overcome for this technology to become viable. For instance, current state-of-the-art electrolytes use organomagnesium salts and complexes as they are the only ones known to be compatible with the $\mathrm{Mg}$ anode that allow for reversible electrochemical $\mathrm{Mg}$ deposition and stripping. ${ }^{[\mathrm{bb}, 6]}$ Although some of these electrolytes have shown impressive stability against electrochemical oxidation, they were also found to be corrosive. ${ }^{[6]}$ This property was attributed to the presence of chlorides in either/both their cations and anions. ${ }^{[6]}$ Conventional inorganic and ionic salts such as $\mathrm{Mg}\left(\mathrm{ClO}_{4}\right)_{2}$ were found to be incompatible with the $\mathrm{Mg}$ anode as a result of the

[*] Dr. R. Mohtadi, Dr. M. Matsui, Dr. T. S. Arthur Materials Research Department

Toyota Research Institute of North America

Ann Arbor, MI 48105 (USA)

E-mail: rana.mohtadi@tema.toyota.com

Dr. S.-J. Hwang

Division of Chemistry and Chemical Engineering California Institute of Technology (USA)

[**] The authors would like to thank Dr. T. Matsunaga and Dr. C. Bucur for the discussions. Funding was provided by Toyota Motor Engineering and Manufacturing North America Inc.

$\square$ Supporting information for this article is available on the WWW under http://dx.doi.org/10.1002/anie.201204913.

0 Re-use of this article is permitted in accordance with the Terms and Conditions set out at http://angewandte.org/open. formation of an ion-blocking layer formed by their electrochemical reduction. ${ }^{[6]}$ Hence, the discovery of halide-free electrolytes with high reductive stabilities is crucial for realizing a practical rechargeable $\mathrm{Mg}$ battery system.

Herein, we propose a new class of electrolytes based on $\mathrm{Mg}\left(\mathrm{BH}_{4}\right)_{2}$ for a $\mathrm{Mg}$ battery. We show the first example of electrochemical reversible $\mathrm{Mg}$ deposition/stripping in a halide-free inorganic salt in both tetrahydrofuran (THF) and dimethoxyethane (DME) solvents. An increase of several orders of magnitude in the current densities, and high coulombic efficiencies of up to $94 \%$ are observed in DME when $\mathrm{LiBH}_{4}$ is used as an additive. Furthermore, we use this electrolyte in a rechargeable $\mathrm{Mg}$ battery, thus giving the first example of a borohydride electrolyte in a battery system. This work also illustrates the unique properties of borohydrides and opens the door for designing a whole new class of electrolytes for $\mathrm{Mg}$ batteries.

$\mathrm{Mg}$ deposition/stripping was studied for $\mathrm{Mg}\left(\mathrm{BH}_{4}\right)_{2}$ in ether solvents. Figure $1 \mathrm{a}$ shows the cyclic voltammogram obtained for $0.5 \mathrm{M} \mathrm{Mg}\left(\mathrm{BH}_{4}\right)_{2} / \mathrm{THF}$ where a reversible reduction-oxidation process took place with onsets at $-0.6 \mathrm{~V} / 0.2 \mathrm{~V}$ and a $40 \%$ coulombic efficiency (Figure $1 \mathrm{a}$, inset), thus indicating reversible $\mathrm{Mg}$ deposition and stripping. X-ray diffraction (XRD) confirmed that the deposited product from the galvanostatic reduction of the above solution (Figure $1 \mathrm{~b}$ ) was hexagonal $\mathrm{Mg}$, hereby establishing the compatibility of $\mathrm{Mg}\left(\mathrm{BH}_{4}\right)_{2}$ with $\mathrm{Mg}$ metal. The electrochemical oxidative stabilities measured on platinum, stainless steel, and glassy carbon electrodes were $1.7,2.2$, and $2.3 \mathrm{~V}$, respectively (Figure S7). These results showed that for the first time: 1) $\mathrm{Mg}\left(\mathrm{BH}_{4}\right)_{2}$ is electrochemically active in THF, that is, ionic conduction is possible, and 2) reversible magnesium deposition/stripping from an inorganic, relatively ionic $(\mathrm{Mg}$ Bader charge is +1.67$)^{[7]}$ and halide-free salt is feasible. Although these results are promising, to make this electrolyte more practical for use in batteries the electrochemical performance needs to be improved by lowering the overpotentials, and achieving higher current density and coulombic efficiency. In addition, the demonstration of this performance in lessvolatile solvents would make $\operatorname{Mg}\left(\mathrm{BH}_{4}\right)_{2}$ based electrolytes even more practical. Therefore, DME was selected (its boiling temperature is $19^{\circ} \mathrm{C}$ higher than that of THF) for further investigations. The cyclic voltammogram obtained for $0.1 \mathrm{M}$ $\mathrm{Mg}\left(\mathrm{BH}_{4}\right)_{2} / \mathrm{DME}$ is shown in Figure $1 \mathrm{c}$ where a substantial improvement in the electrochemical performance compared to $\mathrm{Mg}\left(\mathrm{BH}_{4}\right)_{2} / \mathrm{THF}$ was evident from: 1 ) a 10 -fold increase in the current density, 2) a reduction in the overpotentials (deposition/stripping onsets at $-0.34 \mathrm{~V} / 0.03 \mathrm{~V}$ versus $-0.6 \mathrm{~V} /$ $0.2 \mathrm{~V}$ in THF), and 3) a higher coulombic efficiency of $67 \%$ $(40 \%$ in $\mathrm{THF})$. These findings suggested that the $\mathrm{Mg}$ 


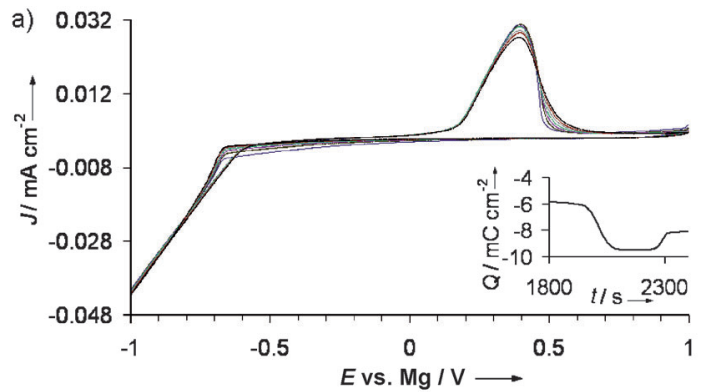

b)

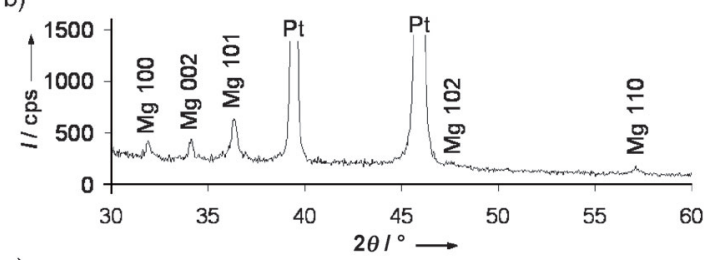

c)

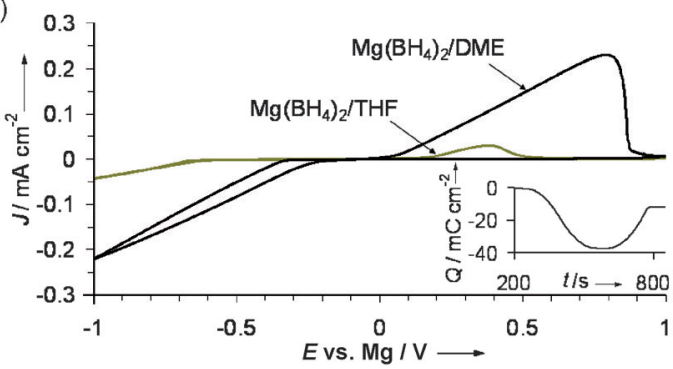

Figure 1. For $0.5 \mathrm{M} \mathrm{Mg}\left(\mathrm{BH}_{4}\right)_{2} / \mathrm{THF}$ : a) Cyclic voltammogram (8 cycles), inset shows deposition/stripping charge balance (third cycle), and b) XRD results following galvanostatic deposition of $\mathrm{Mg}$ on a $\mathrm{Pt}$ working electrode. c) Cyclic voltammogram for $0.1 \mathrm{M} \mathrm{Mg}\left(\mathrm{BH}_{4}\right)_{2} / \mathrm{DME}$ compared to $0.5 \mathrm{M} \mathrm{Mg}\left(\mathrm{BH}_{4}\right)_{2} / \mathrm{THF}$. Inset shows deposition/stripping charge balance for $\mathrm{Mg}\left(\mathrm{BH}_{4}\right)_{2} / \mathrm{DME}$. All experiments used Pt working electrode and $\mathrm{Mg}$ reference/counter electrodes.

electroactive species was present in higher concentration and had increased mobility in DME despite the lower solubility of $\mathrm{Mg}\left(\mathrm{BH}_{4}\right)_{2}$ in DME versus THF.

These results demonstrated that for the $\mathrm{Mg}\left(\mathrm{BH}_{4}\right)_{2}$ electrolyte, the electrochemical performance in DME is higher than that in THF. In contrast, organomagnesium electrolytes show an optimum electrochemical performance in THF ${ }^{[5 b]}$ To further improve the electrochemical performance, it was pertinent to characterize the electroactive species in $\mathrm{Mg}$ $\left(\mathrm{BH}_{4}\right)_{2}$ solutions. Therefore, IR and NMR spectroscopic analyses (Figure 2) were conducted for $0.5 \mathrm{M} \mathrm{Mg}\left(\mathrm{BH}_{4}\right)_{2} / \mathrm{THF}$ and $0.1 \mathrm{M} \mathrm{Mg}\left(\mathrm{BH}_{4}\right)_{2} / \mathrm{DME}$. The IR $\mathrm{B}-\mathrm{H}$ stretching region (2000-2500 $\mathrm{cm}^{-1}$ ) showed two strong widely separated bands $\left(\mathrm{Mg}\left(\mathrm{BH}_{4}\right)_{2} / \mathrm{THF}: 2379 \mathrm{~cm}^{-1}, 2176 \mathrm{~cm}^{-1}\right.$ and $\mathrm{Mg}\left(\mathrm{BH}_{4}\right)_{2} / \mathrm{DME}$ : $\left.2372 \mathrm{~cm}^{-1}, 2175 \mathrm{~cm}^{-1}\right)$; note that the spectra for 0.1 and $0.5 \mathrm{M}$ of $\mathrm{Mg}\left(\mathrm{BH}_{4}\right)_{2}$ in THF are similar (Figure S2). These IR spectra are similar to those of covalent borohydrides ${ }^{[8]}$ and those of $\mathrm{Mg}\left(\mathrm{BH}_{4}\right)_{2}$ solvates from THF and diethyl ether ${ }^{[9]}$ where two hydrogen atoms in $\mathrm{BH}_{4}{ }^{-}$are forming a bridge to one metal atom ( $\mu$ bonding). Therefore, we assigned the bands at the higher and lower $\mathrm{B}-\mathrm{H}$ frequencies to terminal and bridging $\mathrm{B}-\mathrm{H}$ vibrations $\left(\mathrm{B}-\mathrm{H}_{\mathrm{t}}\right.$ and $\left.\mathrm{B}-\mathrm{H}_{\mathrm{b}}\right)$, respectively. The band and shoulder at 2304 and $2240 \mathrm{~cm}^{-1}$ were assigned to asymmetric $\mathrm{B}-\mathrm{H}_{\mathrm{t}}$ and $\mathrm{B}-\mathrm{H}_{\mathrm{b}}$ vibrations, respectively. As complete disso- a)

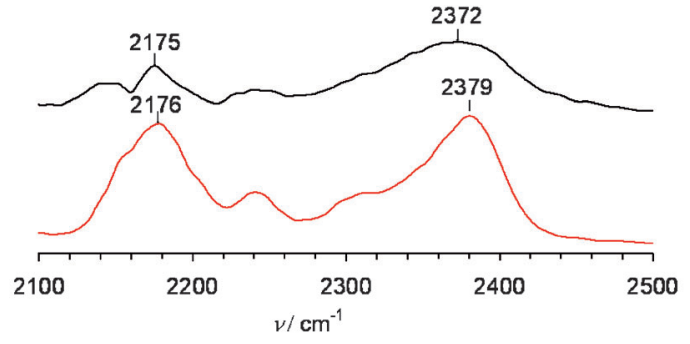

b)

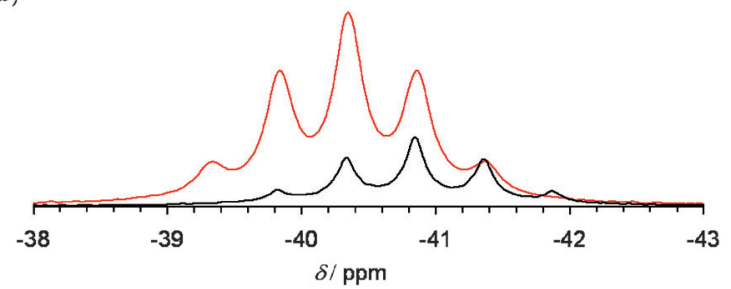

c)

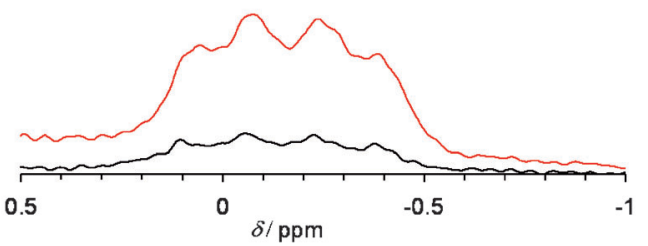

Figure 2. For $\mathrm{Mg}\left(\mathrm{BH}_{4}\right)_{2}$ in THF (red line) and in DME (black line): a) IR spectra, b) ${ }^{11} B$ NMR spectra, and c) ${ }^{1} \mathrm{H}$ NMR spectra.

ciation of $\mathrm{Mg}\left(\mathrm{BH}_{4}\right)_{2}$ into discreet ions is unlikely (as other borohydrides are in ethers $){ }^{[10]}$ we propose that $\mathrm{Mg}\left(\mathrm{BH}_{4}\right)_{2}$ is present as the contact ion pair $\mathrm{Mg}\left[(\mu-\mathrm{H})_{2} \mathrm{BH}_{2}\right]_{2}$, which partially dissociates into $\left[\mathrm{Mg}\left\{(\mu-\mathrm{H})_{2} \mathrm{BH}_{2}\right\}\right]^{+}$and $\mathrm{BH}_{4}^{-}$as in [Eq. (1)]; since the different $\mathrm{B}-\mathrm{H}$ bands most likely overlap, it is not possible to distinguish all the species.

$\mathrm{Mg}\left[(\mu-\mathrm{H})_{2} \mathrm{BH}_{2}\right]_{2} \leftrightarrow\left[\mathrm{Mg}\left\{(\mu-\mathrm{H})_{2} \mathrm{BH}_{2}\right\}\right]^{+}+\mathrm{BH}_{4}$

Where $\left[\operatorname{Mg}\left\{(\mu-\mathrm{H})_{2} \mathrm{BH}_{2}\right\}\right]^{+}$may further dissociate:

$\left[\mathrm{Mg}\left\{(\mu-\mathrm{H})_{2} \mathrm{BH}_{2}\right\}\right]^{+} \leftrightarrow \mathrm{Mg}^{2+}+\mathrm{BH}_{4}$

For the spectrum of $\mathrm{Mg}\left(\mathrm{BH}_{4}\right)_{2} / \mathrm{DME}$, although the main features present in the spectrum of $\mathrm{Mg}\left(\mathrm{BH}_{4}\right)_{2} / \mathrm{THF}$ were retained, the $v \mathrm{~B}-\mathrm{H}_{\mathrm{t}}$ band is broader and shifted to a lower value and the $v B-\mathrm{H}_{b}$ intensity is relatively weaker. Although $v B-H_{t}$ band broadening suggests a pronounced presence of a species similar to that found in THF, the shift in the band maximum indicates a more-ionic $\mathrm{B}-\mathrm{H}$ bond (the $v \mathrm{~B}-\mathrm{H}_{\mathrm{t}}$ shift is similar to those resulting from $\mathrm{BH}_{4}^{-}$ions that have enhanced ionic character, such as in stabilized covalent borohydrides).$^{[8]}$ In addition, the relative weakening in $v \mathrm{~B}-$ $\mathrm{H}_{\mathrm{b}}$ intensity suggests that there is more free $\mathrm{BH}_{4}{ }^{-}$. The NMR spectrum of $\mathrm{BH}_{4}^{-}$in DME (Figure $2 \mathrm{~b}$ and $\mathrm{c}$ ) indicates that there is increased boron shielding as the associated signal is shifted by about $0.5 \mathrm{ppm}$ (quintet in ${ }^{11} \mathrm{~B}$ NMR spectrum), and slightly reduced proton shielding $(0.01 \mathrm{ppm}$, quartet in ${ }^{1} \mathrm{H}$ NMR spectrum); these results are consistent with $\mathrm{B}-\mathrm{H}$ bonds that have a higher ionic character than those in $\mathrm{BH}_{4}^{-}$in THF (distinguishing $\mathrm{B}-\mathrm{H}_{\mathrm{t}}$ from $\mathrm{B}-\mathrm{H}_{\mathrm{b}}$ is not possible likely 
because of rapid hydrogen exchange). These findings are evidence of weaker interactions between $\mathrm{Mg}^{2+}$ and $\mathrm{BH}_{4}^{-}$ within the ion pair and an enhanced dissociation in DME [Eq. (1) and (2)]. So despite the fact that DME has a slightly lower dielectric constant (7.2) compared to THF (7.4), its chelation properties (owing to the presence of two oxygen sites per molecule $)^{[11]}$ resulted in an enhanced dissociation and thus an improved electrochemical performance.

Based on the understanding gained of the nature of $\mathrm{Mg}\left(\mathrm{BH}_{4}\right)_{2}$ in solution, we hypothesized that electrochemical performance would be enhanced when the association within the ion pair is weakened. To achieve this, an additive that has an acidic cation with the following characteristics is desirable: 1) reductive stability comparable to $\left.\mathrm{Mg}\left(\mathrm{BH}_{4}\right)_{2}, 2\right)$ nonreactive, 3) halide free, and 4) soluble in DME. Hence, $\mathrm{LiBH}_{4}$ was selected as it fulfils all of the above criteria. Mg deposition and stripping was studied in DME using different molar ratios of $\mathrm{LiBH}_{4}$ to $\mathrm{Mg}\left(\mathrm{BH}_{4}\right)_{2}$; Figure 3 a shows the cyclic voltammo-

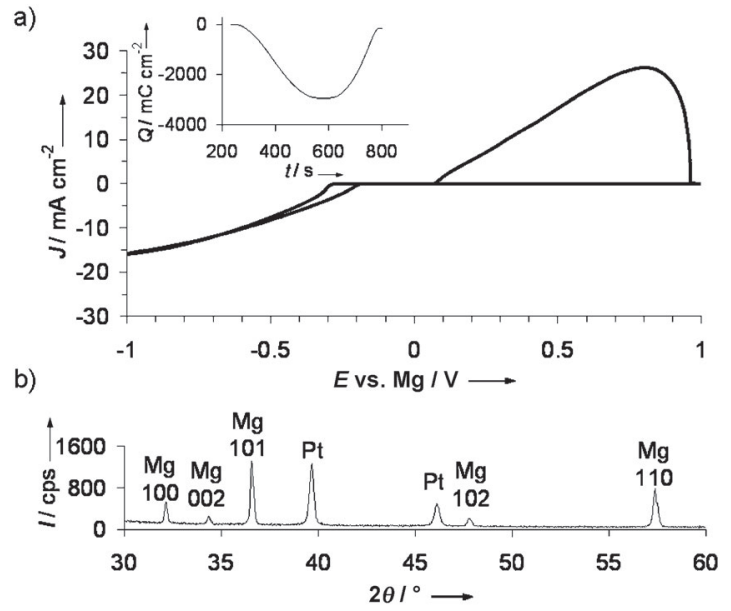

c)

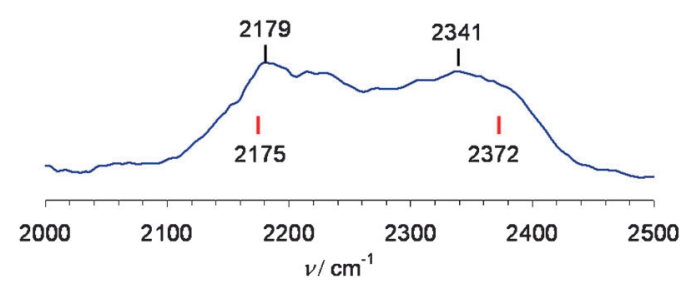

Figure 3. For $\mathrm{LiBH}_{4}(0.6 \mathrm{M}) / \mathrm{Mg}\left(\mathrm{BH}_{4}\right)_{2}(0.18 \mathrm{M})$ in DME: a) Cyclic voltammogram (inset shows deposition/stripping charge balance). b) XRD results following galvanostatic deposition of $\mathrm{Mg}$ on a $\mathrm{Pt}$ disk. c) IR spectra (red | indicates band maxima for $\mathrm{Mg}\left(\mathrm{BH}_{4}\right)_{2} / \mathrm{DME}$ ).

gram obtained for 3.3:1 molar $\mathrm{LiBH}_{4}$ to $\mathrm{Mg}\left(\mathrm{BH}_{4}\right)_{2}$ (Figure $\mathrm{S} 8 \mathrm{a}$ and $\mathrm{S} 8 \mathrm{~b}$ show the cyclic voltammograms for different concentrations). The use of $\mathrm{LiBH}_{4}$ resulted in an increase of two orders of magnitude in the current density (i.e. oxidation peak current $\mathrm{Jp}=26 \mathrm{mAcm}^{-2}$ ), and in a higher coulombic efficiency of up to $94 \%$. We attribute the deposition/stripping currents solely to $\mathrm{Mg}$ because of the absence of Li after galvanostatic deposition (Figure $3 \mathrm{~b}$ ), and also the lack of electrochemical activity in a $\mathrm{LiBH}_{4} / \mathrm{DME}$ solution (Figure S8a). The ionic character of $\mathrm{BH}_{4}^{-}$was enhanced, as evidenced by lower $v B-H_{t}$ and higher $v B-H_{b}$ bands in the IR spectrum (Figure 3c), thus implying that $\mathrm{LiBH}_{4}$ has a role in increasing $\mathrm{Mg}\left(\mathrm{BH}_{4}\right)_{2}$ dissociation (the $\mathrm{B}-\mathrm{H}$ bands for $\mathrm{LiBH}_{4}$ / DME occur at lower values, Figure S9). The coulombic efficiency was proportional to the molar ratios of $\mathrm{LiBH}_{4} /$ $\mathrm{Mg}\left(\mathrm{BH}_{4}\right)_{2}$ (Figure $\mathrm{S} 10$ ). A rechargeable $\mathrm{Mg}$ battery with a Chevrel phase $\mathrm{Mo}_{6} \mathrm{~S}_{8}$ cathode, an $\mathrm{Mg}$ metal anode, and this optimized electrolyte (Figure 4) demonstrated reversible cycling capabilities at a $128.8 \mathrm{mAg}^{-1}$ rate (capacity retention and cathode magnesiation are shown in Figure S11 and Figure S12). We are currently investigating the sources of the overcharge and capacity fade.

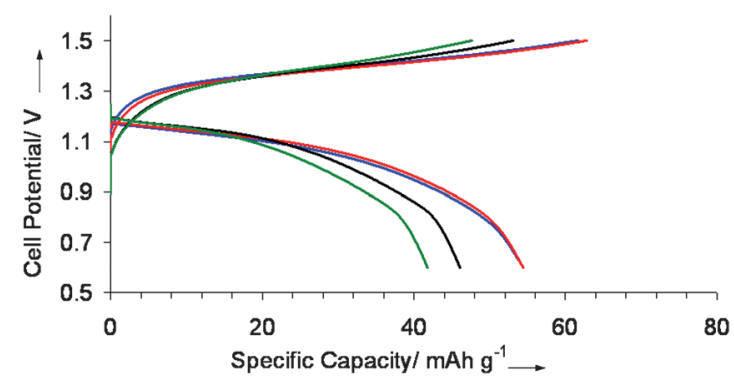

Figure 4. Charge/discharge profiles with $\mathrm{Mg}$ anode/Chevrel phase cathode for 3.3 molar $\mathrm{LiBH}_{4} / \mathrm{Mg}\left(\mathrm{BH}_{4}\right)_{2}$ in DME. Cycle 1 (blue), cycle 2 (red), cycle 20 (black), cycle 40 (green).

In summary, unprecedented reversible $\mathrm{Mg}$ deposition and stripping from an inorganic and relatively ionic salt was obtained in THF and DME. Higher current density and lower overpotentials were achieved in DME compared to those in THF. Substantial enhancement in the coulombic efficiency and the current density was accomplished by the addition of $\mathrm{LiBH}_{4}$. Battery performance was demonstrated using a Chevrel phase cathode. Although the oxidative stability $(1.7 \mathrm{~V}$ vs. $\mathrm{Mg}$ on platinum) currently limits $\mathrm{Mg}\left(\mathrm{BH}_{4}\right)_{2}$ utilization with high voltage cathodes, reversibility in the absence of halides and THF makes this salt extremely unique and these findings very important for designing a whole new class of $\mathrm{Mg}\left(\mathrm{BH}_{4}\right)_{2}$ based electrolytes. Currently, we are investigating improving the oxidative stability of $\mathrm{Mg}\left(\mathrm{BH}_{4}\right)_{2}$. In addition, the exact nature of the electroactive species in the presence and the absence of the additive is being studied to guide the design of $\mathrm{Mg}\left(\mathrm{BH}_{4}\right)_{2}$ based electrolytes. This work provides a stepping stone for extending the applications of $\mathrm{Mg}\left(\mathrm{BH}_{4}\right)_{2}$ and underscores the beauty and versatility of the chemistry of borohydrides.

\section{Experimental Section}

Magnesium borohydride $\left(\mathrm{Mg}\left(\mathrm{BH}_{4}\right)_{2}, 95 \%\right)$ lithium borohydride $\left(\mathrm{LiBH}_{4}, 90 \%\right)$, anhydrous tetrahydrofuran (THF), and dimethoxyethane (DME) were purchased from Sigma-Aldrich. Cyclic voltammetry was conducted in a three-electrode cell with $\mathrm{Mg}$ wire/ribbon as reference/counter electrodes. The electrochemical testing was conducted in an argon filled glovebox with $\mathrm{O}_{2}$ and $\mathrm{H}_{2} \mathrm{O}$ amounts kept 
below $0.1 \mathrm{ppm}$. Details of the analyses and battery testing conducted are described in the Supporting Information.

Received: June 23, 2012

Published online: August 21, 2012

Keywords: borohydrides · electrochemistry · hydrogen . magnesium

[1] B. Bogdanović, M. Schwickardi, J. Alloys Compd. 1997, $253-$ 254,1 .

[2] a) H.-W. Li, Y. Yan, S. Orimo, A. Züttel, C. M. Jensen, Energies 2011, 4, 185; b) R. Mohtadi, P. Sivasubramanian, S.-J. Hwang, A Stowe, J. Gray, T. Matsunaga, R. Zidan, Int. J. Hydrogen Energy 2012, 37, 2388.

[3] E. Wiberg, R. Bauer, Z. Naturforsch. B 1950, 5, 397.

[4] K. Chłopek, C. Frommen, A. Leòn, O. Zabara, M. Fichtner, J. Mater. Chem. 2007, 17, 3496.
[5] a) D. Aurbach, Z. Lu, A. Schechter, Y. Gofer, H. Gizbar, R. Turgeman, Y. Cohen, M. Moshkovich, E. Levi, Nature 2000, 407, 724; b) N. Amir, Y. Vestfrid, O. Chusid, Y. Gofer, D. Aurbach, J. Power Sources 2007, 174, 1234; c) M. Armand, J. Tarascon, Nature 2008, 451, 652; d) H. S. Kim, T. S. Arthur, G. D. Allred, J. Zajicek, J. G. Newman, A. E. Rodnyansky, A. G. Oliver, W. C. Boggess, J. Muldoon, Nat. Commun. 2011, 2, 427.

[6] J. Muldoon, C. B. Bucur, A. G. Oliver, T. Sugimoto, M. Matsui, H. S. Kim, Energy Environ. Sci. 2012, 5, 5941.

[7] Z. Łodziana, M. J. Van Setten, Phys. Rev. B 2010, 81, 024117.

[8] a) N. Davies, P. H. Bird, M. G. H. Wallbridge, J. Chem. Soc. A 1968, 2269; b) P. Sivasubramanian, R. Mohtadi, R. Zidan, K. Pariyadat, C. L. Levertte, M. L. Fetterolf, Appl. Spectrosc. 2012, 66, 591.

[9] a) H. Nöth, Z. Naturforsch. B 1982, 37, 1499; b) M. Bremer, H. Nöth, M. Warchhold, Eur. J. Inorg. Chem. 2003, 111.

[10] A. E. Shirk, D. F. Shriver, J. Am. Chem. Soc. 1973, 95, 5901.

[11] N. S. Poonia, A. V. Bajaj, Chem. Rev. 1979, 79, 389. 